\title{
COMPLEMENT LEVELS IN BRAZILIAN CHILDREN DURING AND AFTER MENINGOCOCCAL MENINGITIS
}

Pérsio Roxo Júnior'1, Virgínia Paes Leme Ferriani², José Eduardo Teixeira ${ }^{3}$, and José Elpídio Barbosa ${ }^{4}$

ROXO Jr. P et al. Complement levels in Brazilian children during and after meningococcal meningitis. CLINICS 60(2):127$130,2005$.

PURPOSE: To evaluate the functional activity of the classical and alternative pathways of the complement system and the levels of $\mathrm{C} 3, \mathrm{C} 4$, and factor B during the first episode of meningococcal infection and during the convalescence period.

PATIENTS AND METHODS: Ten Brazilian children ranging in age from 8 months to 8 years, admitted from 1991 to 1993 with a clinical-laboratory diagnosis of meningococcal meningitis, were studied during acute infection (up to 7 days from diagnosis) and during the convalescence period (1 to 6 months after the acute episode). C3, C4, and Factor B were measured using nephelometry, and the lytic activity of classical and alternative pathways were evaluated by a kinetic method and expressed as the time needed to lyse $50 \%$ of an erythrocyte suspension (T1/2, expressed in seconds). Low T1/ 2 values for classical and alternative pathways correlate with high activities of the classical and alternative complement pathways, respectively.

RESULTS: A significant difference was observed between the alternative pathway lytic activity during infection and the convalescence period ( 282 vs 238 seconds, respectively, $P=.01$ ). No differences were detected in the other complement parameters analyzed.

CONCLUSIONS: In the presence of meningococcal meningitis, the alternative pathway is preferentially activated. This is probably due to the greater ability of the meningococcal endotoxin to activate this pathway in vivo.

KEYWORDS: Complement. Classical pathway. Alternative pathway. Lytic activity. Meningococcal meningitis.

Activation of complement by gram-negative bacteria can occur via the classical (CP) or the alternative pathway (AP). ${ }^{1}$ Complement levels are often abnormal in patients with an acute meningococcal infection. ${ }^{2}$ Activation of the $\mathrm{CP}$ or low levels of C3 during meningococcal meningitis have been reported in different countries including Nigeria $^{3}$, Brazil, ${ }^{4}$ and the United States. ${ }^{5}$ Moreover, a significant depression in functional activity of the $\mathrm{CP}$ and of $\mathrm{C} 3$ and factor $\mathrm{B}$ levels has been reported in children with severe meningococcal infection, suggesting that activation of both the $\mathrm{CP}$ and

From the Department of Pediatrics, ${ }^{1,2}$ and Department of Biochemistry and Immunology, ${ }^{3,4}$ School of Medicine of Ribeirão Preto, University of São Paulo - Ribeirão Preto/SP Brazil.

E-mail: jebarbos@fmrp.usp.br

Received for publication on December 06, 2004.

Accepted for publication on December 13, 2004. the AP occurs in this particular setting. ${ }^{2}$ Activation of AP in patients with gram-negative bacteriemia and shock has been demonstrated. ${ }^{6}$ In the present study, we measured the lytic activity of the $\mathrm{CP}$ and $\mathrm{AP}$, as well as the levels of $\mathrm{C} 3$, $\mathrm{C} 4$, and factor $\mathrm{B}$ in Brazilian children during and after the first episode of meningococcal meningitis in order to assess the activation of both complement pathways in this disease.

\section{METHODS}

All procedures were in accordance with the ethical standards of the institutional committee on human experimentation. Ten consecutive patients with ages ranging from 8 months to 8 years with acute meningococcal meningitis were studied during the acute infection phase (up to 7 days 
from diagnosis) and during the convalescence period (between 1 and 6 months after the cure). The inclusion criteria were clinical signs of meningococcal infection, absence_of autoimmunity and other infectious diseases, and normal nutritional status. All of the participants were from Ribeirão Preto and were diagnosed between 1991 and 1993. The diagnosis of meningococcal infection was based on clinical signs and confirmed by bacteriologic exams. Blood samples were collected by venipuncture from patients and left to clot at room temperature for 90 minutes. Serum was obtained by centrifugation at $4^{\circ} \mathrm{C}$, pooled, sampled, frozen in liquid nitrogen, and stored at $-70^{\circ} \mathrm{C}$ until analysis in 1994. The lytic complement activity of $\mathrm{CP}$ and $\mathrm{AP}$ was measured by means of a kinetic assay, as previously described, with minor modifications. ${ }^{78}$ Briefly, the time required to lyse $50 \%$ of an erythrocyte suspension was measured (T1/2). Low T1/2 values for $\mathrm{CP}$ and $\mathrm{AP}$ correlate with high $\mathrm{CP}$ and AP complement activities, respectively. For the CP assay, a suspension of sensitized sheep red blood cells (SRBC) in triethanolamine-buffered saline containing $0.1 \%$ gelatin, $0.5 \mathrm{mM} \mathrm{Mg}^{++}$, and $0.15 \mathrm{mM} \mathrm{Ca}^{++}\left(\mathrm{TBS} \mathrm{Mg}^{++} \mathrm{Ca}^{++}\right.$) was standardized at concentrations sufficient to reach an optical density of 1.5 units at $700 \mathrm{~nm}$ when mixed with the diluted serum sample. For the AP assay, uncoated rabbit erythrocytes $(\mathrm{RaBC})$ in triethanolamine-buffered saline containing $0.1 \%$ gelatin, $2 \mathrm{mM} \mathrm{Mg}{ }^{++}$, and $8 \mathrm{mM}$ ethylene-glycol-bis (b-aminoethyl ether) N, N, N', N', -tetraacetic acid (TBS- $\mathrm{Mg}^{++}$EGTA) were standardized as described for the sheep erythrocytes. The final serum dilution of the samples was 1:38 for the CP and 1:6 for the AP experiments. The concentrations of $\mathrm{C} 3, \mathrm{C} 4$, and factor B were assayed by kinetic nephelometry with an Immunochemistry Analyzer ICS II (Beckman Instruments Inc. Diagnostic System Group, Galway, Ireland).
Statistical analysis using the Student paired $t$ test was performed to compare complement levels during infection and the convalescence period.

\section{RESULTS}

The individual values obtained for $\mathrm{CP}$ lytic activity during the acute phase of meningitis and after infection were within the normal estimated range for age-matched Brazilian children. No significant differences were found between the arithmetic means of $\mathrm{CP}$ activity during (143 seconds) and after (149 seconds) meningococcal meningitis (Table 1). On the other hand, 3 out of 10 children studied $(30 \%)$ had higher AP T1/2 values during acute meningitis than the upper limit estimated for their age, indicating a lower AP activity in these children (Table 2). One child maintained high AP T1/2 times during the convalescence period. Unfortunately, we could not contact this child afterwards to complete the investigation. The AP activity during acute infection was significantly lower compared to that observed after infection (Table 2). Concentrations of $\mathrm{C} 3, \mathrm{C} 4$, and factor $\mathrm{B}$ during the acute phase were higher than the upper limit of age-matched Brazilian children in $66.7 \%$, $44.5 \%$, and $55.5 \%$ of the patients, respectively (data not shown). No significant differences were found in the levels of C3, $\mathrm{C} 4$, or factor $\mathrm{B}$ during or after meningitis.

\section{DISCUSSION}

Systemic inflammation by activated complement and cytokines is important in the pathogenesis of meningoccocal disease. ${ }^{9}$

Our results suggest that AP activation occurs during acute meningococcal meningitis, since we have observed

Table 1 - Classical pathway (CP) hemolytic activity, expressed as T1/2 (in seconds), during and after meningococcal meningitis.

\begin{tabular}{|c|c|c|c|c|}
\hline Patients & Age & Reference values*(seconds) & $\begin{array}{l}\mathrm{CP}(\mathrm{T} 1 / 2 \text { in seconds) } \\
\text { Infection }\end{array}$ & Convalescence \\
\hline 1 & 8 months & $108-255$ & 193 & 170 \\
\hline 2 & 10 months+ & $108-255$ & 198 & 127 \\
\hline 3 & 1 year & $108-255$ & 127 & 201 \\
\hline 4 & 2 years & $121-218$ & 120 & 105 \\
\hline 5 & 4 years & $104-300$ & 140 & 133 \\
\hline 6 & 4 years & $104-300$ & 89 & 120 \\
\hline 7 & 3 years+ & $104-300$ & 128 & 147 \\
\hline 8 & 8 years+ & $107-306$ & 155 & 184 \\
\hline 9 & 2 years & $121-218$ & 116 & 120 \\
\hline 10 & 8 years & $107-306$ & 161 & 180 \\
\hline Mean & & & $143 \dagger$ & 149 \\
\hline
\end{tabular}

(*) Reference values according to age as established by Ferriani, Barbosa \& Carvalho. ${ }^{7}$

(+) Children with meningococcemia

(†) $P=.44$ 
Table 2 - Alternative pathway (AP) hemolytic activity, expressed as T1/2 (in seconds), during and after menigococcal meningitis.

\begin{tabular}{|c|c|c|c|c|}
\hline Patients & Age & Reference values*(seconds) & $\begin{array}{l}\mathrm{AP}(\mathrm{T} 1 / 2 \text { in seconds) } \\
\text { Infection }\end{array}$ & Convalescence \\
\hline 1 & 8 months & $172-305$ & 374 & 252 \\
\hline 2 & 10 months+ & $172-305$ & 297 & 257 \\
\hline 3 & 1 year & $172-305$ & 275 & 173 \\
\hline 4 & 2 years & $184-273$ & 321 & 240 \\
\hline 5 & 4 years & $177-301$ & 225 & 200 \\
\hline 6 & 4 years & $177-301$ & 339 & 336 \\
\hline 7 & 3 years + & $177-301$ & 243 & 249 \\
\hline 8 & 8 years + & $171-274$ & 248 & 238 \\
\hline 9 & 2 years & $184-273$ & 239 & 204 \\
\hline 10 & 8 years & $171-274$ & 261 & 228 \\
\hline Mean & & & $282 \dagger$ & 238 \\
\hline
\end{tabular}

(*) Reference values according to age as established by Ferriani, Barbosa \& Carvalho.?

(+) Children with meningococcemia

(†) $P=.01$

significantly decreased AP hemolytic activity in the acute phase of this infection, as compared to the convalescence period. This is in accordance with the known ability of the meningococcal endotoxin to activate the AP in vivo. ${ }^{10} \mathrm{We}$ did not find evidence of activation of the $\mathrm{CP}$ in these patients, since the T1/2 times were similar for both periods. In another Brazilian study, investigators used the CH50 assay for total complement (CH50 levels) and an assay for C3 levels in 25 patients, including 8 children, with meningococcal meningitis. ${ }^{4}$ Although they reported significantly reduced $\mathrm{CH} 50$ levels in the patients when compared to normal adults, all 8 children studied presented CH50 levels within the normal range for adults. These results are not in accordance with those reported in yet another study, ${ }^{2}$ in which normal AP50 and decreased CH50 levels in children with meningococcal infection compared to normal adults was found. However, these investigators did not compare the values during and after the infection. They also found significantly lower complement levels, particularly regarding the $\mathrm{CH} 50$ assay, $\mathrm{C} 3$, and factor $\mathrm{B}$, in more severely affected children, including those who developed septicemia. In a case report, 36-year-old patient with meningoccocal meningitis had undetectable levels of $\mathrm{C} 7$ and total complement as revealed by the $\mathrm{CH} 50$ assay. So it appears that the best screen for complement deficiencies or significant activation is the CH50 assay. ${ }^{11}$ Complete non-response in the $\mathrm{CH} 50$ assay associated with normal $\mathrm{C} 3$ levels is a strong indication for complement deficiency and should be followed up with further tests. ${ }^{12}$ In spite of our limited number of cases, it is worth mentioning that 3 out of 10 children studied presented meningococcemia, and their AP and $\mathrm{CP}$ activity levels were not different from those estimated for normal age-matched Brazilian children. One of the patients (\# 6) maintained a higher than normal AP T1/2 during the convalescence period. Since we were not able to contact this patient afterwards, we could not establish whether this child presented a transient alteration or a partial deficiency of properdin or of factor D. Properdin deficiency has been associated with severe meningoccocal disease. In a study in 3 generations of a large Swiss family, the concentration of circulating properdin in affected males was $<0.1 \mathrm{mg} / \mathrm{L}$, indicating properdin deficiency type $\mathrm{I}$, and 2 of the 9 properdin-deficient males in the family had survived meningitis caused by Neisseria meningitidis serogroup B without sequelae. ${ }^{13}$

No significant differences occurred between the mean levels of $\mathrm{C} 3, \mathrm{C} 4$, and factor B during and after meningococcal meningitis. Some of the children showed a non-significant trend towards increased levels of factor B, C3, and C4 as compared to normal controls, suggesting that these components were acting as acute phase proteins, as previously reported in many infectious conditions. ${ }^{14}$ These results suggest that in the presence of an infectious episode, the alternative pathway is preferentially activated, probably due to the greater capacity of the meningococcal endotoxin to activate this pathway in vivo. The assessment of properdin levels and of more sensitive markers of complement activation, such as C3a, C3d, C5a, Ba, and soluble C5b-9 complex during and after meningococcal infection are needed to better understand the role of complement in meningitis.

\section{ACKNOWLEDGEMENTS}

We would like to thank Prof. Luis de Souza for helping with the statistical analysis. The study was supported by grants from the Fundação de Amparo à Pesquisa do Estado de São Paulo (FAPESP) and the Fundação Coordenação de Aperfeiçoamento de Pessoal de Nivel Superior (CAPES). 
ROXO Jr. P e col. Níveis de complemento em crianças brasileiras durante e após meningite meningocócica. CLINICS 60(2):127-130, 2005.

OBJETIVO: Avaliar a atividade funcional das vias clássica e alternativa do sistema complemento e os níveis de C3, C4 e fator B durante o primeiro episódio de infecção meningocócica e durante a convalescença.

PACIENTES E MÉTODOS: Dez crianças brasileiras com idades entre 8 meses e 8 anos, admitidas de 1991 a 1993, com diagnóstico clínico-laboratorial de meningite meningocócica, foram estudadas durante infecção aguda (até 7 dias do diagnóstico) e no período de convalescença (entre 1 e 6 meses após). C3, C4 e fator B foram quantificados por nefelometria e a atividade lítica das vias clássica e alternativa foi avaliada por método cinético e expressa como tempo necessário para lisar 50\% de uma suspen- são de eritrócitos (T1/2, expresso em segundos). Baixos valores de T1/2 das vias clássica e alternativa se correlacionam com elevadas atividades de via clássica e via alternativa, respectivamente.

RESULTADOS: Observaram-se diferenças significativas entre a atividade lítica da via alternativa durante a infecção e no período de convalescença (282 e 238 segundos, respectivamente, $P=.01$ ). Nenhuma diferença foi detectada nos outros parâmetros analisados.

CONCLUSÕES: Na presença de meningite meningocócica a via alternativa é preferencialmente ativada, provavelmente devido à maior capacidade da endotoxina meningocócica para ativar esta via, in vivo.

UNITERMOS: Complemento. Via clássica. Via alternativa. Atividade lítica. Meningite meningocócica.

\section{REFERENCES}

1. Taylor PW. Bactericidal and bacteriolytic activity of serum against Gram-negative bacteria. Microbiol Rev 1983;47:46-83.

2. Beatty DW, Ryder CR, De V Heese H. Complement abnormalities during an epidemic of Group B meningococcal infection in children. Clin Exp Immunol 1986;64:465-70.

3. Greenwood BM, Onyewotu II, Whittle HC. Complement and meningococcal infection. Br Med J 1976;1:797-9.

4. Ribeiro MG, Fava-Netto C, Dos Santos MP. Determinação do complemento hemolítico total e do componente $\mathrm{C} 3 \mathrm{em}$ pacientes de meningite meningocócica. Rev Inst Med Trop São Paulo 1981;23:185-87.

5. Hoffman TA, Edwards EA. Group-specific polyssacharide antigen and humoral antibody response in disease due to Neisseria menigitidis. J Infect Dis 1972;126:636-44.

6. Fearon DT, Ruddy S, Schur PH, McCabe WR. Activation of the properdin pathway of complement in patients with gramnegative bacteremia. N Engl J Med 1975;292:937-40.

7. Ferriani VL, Barbosa JE, Carvalho IF - Serum hemolytic classical and alternative pathways of complement in infancy: age-related changes. Acta Paediatr Scand 1990;79:322-27.

8. Ferriani VPL, Barbosa JE, Carvalho IF. Complement haemolytic activity (classical and alternative pathways), C3, C4 and factor B titres in healthy children. Acta Paediatr 1999; 88:1062-6.
9. Sprong T, Moller AS, Bjerre A, Wedege E, Kierulf P, van der Meer JW, et al. Complement activation and complement-dependent inflammation by Neisseria meningitidis are independent of lipopolysaccharide. Infect Immunol 2004;72:3344-9.

10. Ross SC, Densen P. Complement deficiency states and infection: Epidemiology, pathogenesis, and consequences of neisseria and other infections in an immune deficiency. Medicine 1984;63:243-73.

11. Corvini M, Randolph C, Aronin SI - Complement C7 deficiency presenting as recurrent aseptic meningitis. Ann Allergy Asthma Immunol 2004;93:200-5.

12. Fremeaux-Bacchi V, Dragon-Durey MA, Blouin J, Mouthon L, Fridman WH. Investigation of the complement system in clinical practice. Ann Med Interne 2003;154:529-40.

13. Spath PJ, Sjoholm AG, Fredrikson GN, Misiano G, Scherz R, Schaad UB, et al. Properdin deficiency in a large Swiss family: identification of a stop codon in the properdin gene and association of meningococcal disease with lack of the $\operatorname{IgG} 2$ allotype marker G2m (n). Clin Exp Immunol 1999;118:27884.

14. Blasi F, Tarsia P, Aliberti S. Strategic target of essential host-pathogen interactions. Respiration 2005; 72(1): 9-25.. 